\title{
Nodular thyroid disease in the erderly
}

\author{
A Belfiore \\ From de Senectute: Age and Health Forum \\ Catanzaro, Italy. 5-7 December 2009
}

The occurrence of thyroid nodules increases with age [1]. In geographical areas with a normal iodine intake, approximately $10 \%$ of the population develops a palpable thyroid nodule. This proportion increases in areas with insufficient iodine intake. Non-palpable thyroid nodules are usually diagnosed by a neck echography carried out for various reasons and are 5-10 folds more common than palpable nodules.

When evaluating a thyroid nodule, we must be aware that two conditions require particular attention: a) the possibility of a "hot" (hyperfunctioning) nodule, which can induce thyrotoxicosis; b) the possibility of a malignant nodule.

Both these pathological conditions increase with age $[2,3]$. In particular, elderly patients often show a multinodular goiter, where both hyperfunctioning nodules and hypofunctioning nodules suspicious for malignancy may coexist. When FT3 is high and/or TSH is suppressed a hyperfunctioning nodule should be suspected. In order to confirm this diagnosis the patient should carry out a thyroid scintigram. In the case that both FT3 and TSH are in the normal range, the nodule should be regarded as non-functioning. In this case a thyroid scintigram is not useful whereas a fine needle aspiration (FNAB) is the diagnostic procedure of choice [4].

Both hyperfunctioning and malignant thyroid nodules are more common in elderly patients. Notably, hyperthyroidism is a more serious condition in the elderly than in the young because of an increased risk of cardiac dysfunction. Moreover, thyroid cancer behaves more aggressively in elderly patients. In these patients thyroid cancer is usually less differentiated and lacks the ability to concentrate iodine. Therefore, thyroid cancer metastases cannot be treated with radioiodine.

In the case of a hyperfunctioning nodule the therapy of choice is a thyroid lobectomy. In contrast, in the case

Department of Clinical and Experimental Medicine, Endocrinology, University of Catanzaro, Universitary Campus, Catanzaro, Italy of a multinodular goiter or of a malignant nodule, a total thyrodectomy is required.

Published: 19 May 2010

\section{References}

1. Mazzaferri EL: Management of a solitary thyroid nodule. N Engl J Med 1993, 328:553-559.

2. Belfiore A, Sava L, Runello F, Tomaselli L, Vigneri R: Solitary autonomously functioning thyroid nodules and iodine deficiency. J Clin Endocrinol Metab 1983, 56:283-287.

3. Belfiore A, La Rosa GL, La Porta GA, Giuffrida D, Milazzo G, Lupo L, Regalbuto $C$, Vigneri $R$ : Cancer risk in patients with cold thyroid nodules: relevance of iodine intake, sex, age, and multinodularity. Am J Med 1992, 93:363-369.

4. Belfiore A, La Rosa GL: Fine-needle aspiration biopsy of the thyroid. Endocrinol Metab Clin North Am 2001, 30:361-400.

doi:10.1186/1471-2318-10-S1-L19

Cite this article as: Belfiore: Nodular thyroid disease in the erderly. BMC Geriatrics 2010 10(Suppl 1):L19.
Submit your next manuscript to BioMed Central and take full advantage of:

- Convenient online submission

- Thorough peer review

- No space constraints or color figure charges

- Immediate publication on acceptance

- Inclusion in PubMed, CAS, Scopus and Google Scholar

- Research which is freely available for redistribution

Submit your manuscript at www.biomedcentral.com/submit
C Biomed Central 